\title{
Extent of Adoption of Improved Agricultural Production Practices in Aizawl District of Mizoram
}

\author{
K. P. Chaudhary*, Santosh Kumar, N. Jotish, Joshi Kumar and P. Lalvensanga \\ Krishi Vigyan Kendra, Central Agricultural University, Aizawl, Mizoram, India \\ *Corresponding author
}

\section{A B S T R A C T}

Keywords

Level of

knowledge, Impact,

Training

programme,

Adoption level,

Satisfaction level

Article Info

Accepted:

04 December 2020

Available Online:

10 January 2021
The present investigation was undertaken in Aizawl district of Mizoram. A multistage sampling design was used to select the sample farmers as respondents. A total of 180 farmers were selected as respondent for the study purpose. The primary data required for the study were collected from selected sample respondents through specially prepared interview schedule. It was noted that nearly 85 per cent beneficiary respondents had high to medium level of adoption of improved agricultural production technologies. While, only 15.83 per cent of the respondents had low level of adoption. In case of non-beneficiary respondents majority of the farmers $(45.00 \%)$ had low level of adoption of improved technologies. The results clearly indicated that the overall adoption quotients for different aspects of agricultural production practices were highly skewed towards beneficiary respondents. Mean adoption quotient of beneficiary respondent was significant higher over the mean adoption quotient of non-beneficiary respondents.

\section{Introduction}

Agriculture has now become extremely competitive. Practicing agriculture demands to be innovative, nature friendly, relying on farmers' wisdom and make use of modern development of science. Use of science and technology, knowledge empowerment and capacity building can enable farmers to make them competitive and induce inclusive growth. So far, the achievements in respect of agricultural growth and food production have been spectacular with self-sufficiency in food grains. There is still untapped potential of currently available agricultural technologies, which can help mitigate the effects of shrinking cultivable land, scarcity of irrigation water, soil nutrient depletion, increasing biotic and a biotic stress etc. The farming has to be sustainable and profitable in different resource environment in order to bring in financial and livelihood security for rural households. To address issues related to technology dissemination in agriculture, the Krishi Vigyan Kendra (KVK), known also as Agriculture Science Centre, a grass root level scheme has been designed and nurtured by Indian Council of Agricultural Research (ICAR) for the past four decades. A considerable time has passed after the 
initiation of the KVKs and it is time to take stock of the situation, especially on the performance appraisal. Therefore, the questions arise whether there is an impact of Krishi Vigyan Kendra on the beneficiary farmers' adoption of agricultural technologies, and ultimately on the level of agricultural development in the district. So, keeping these aspects in mind, a study entitled "Impact assessment of service given by Krishi Vigyan Kendra in Aizawl District of Mizoram in term of technology adoption" has been conducted with the following specific objectives: (i) To study the socio-economic attributes of KVK beneficiaries (ii) To study the impact of KVK services on adoption of improved agricultural production practices.

\section{Materials and Methods}

The present investigation was undertaken in Aizawl District of Mizoram. A multi-stage sampling design was used to select the sample farmers as respondents. In first stage, Aizawl district was selected purposively. In second stage, two Blocks (Tlangnuam and Aibawk) from Aizawl district were selected. In third stage, three villages adopted (Muthi, Sihphir and aibawk) by Krishi Vigyan Kendra, were selected from each selected Block. Finally at last stage a comprehensive list of all the beneficiary farmers from each selected village was prepared with help of records of Krishi Vigyan Kendra. From each sample village, 20 beneficiary farmers were selected through randomly sampling method as respondents for the study purpose. Apart from this, in order to assess the impact of Krishi Vigyan Kendra in terms of adoption of improved agriculture production practices, a sample of 60 nonbeneficiary farmers was selected from control villages. Thus, a total of 180 farmers were selected as respondent for the study purpose. The primary data required for the study were collected from selected sample respondents through specially prepared schedules. The schedule included the data relating to the profile of respondents, adoption of various improved agricultural practices. The entire schedule was subjected to pre-testing before administering it to the actual respondents. The schedule was improved and revised according to the suggestions received from the respondents. The primary data required for the study were collected through recall method in one round. The data so collected were transferred to the work table and tally sheets. They were processed, tabulated, classified, analyzed, and given statistical treatment. The cross tables were also prepared and the data were interpreted. The hypotheses formulated were tested and salient interpretations were drawn from the data in light of the objectives of the study. To measure the extent of adoption of improved agriculture production technologies an index was developed by following the recommended procedures. The respondents were asked to respond to each item of adoption of these practices with respect to their extent of adoption on a five point continuum namely 'full adoption' (5), 'partial adoption' (4), 'less adoption' (3), 'symbolic adoption' (2), 'non adoption' (1) with respective weightages accorded. Here, full adoption is operationalized as the adoption of stated practice completely and regularly in each season of a year continuously for three year period. Partial adoption is operationalized as the adoption of only a part or whole of recommended practice once in year continuously for three year period. Less adoption was operationalized as the adoption of only a part of recommended practice once in a three years period. Symbolic adoption was operationalized as the practices over which he has taken mental decision but not taken up physical action over them. Non adoption was operationalized as that recommended practices were not all adopted by the farmer. Based on the response of each item, total score of individual farmers was 
computed by summing up those scores. Thus, total score secured by an individual was the obtained adoption score. The adoption quotient was worked out for each respondent by following quotient and it was taken as the adoption score for individual responded.

Adoption quotient $(\mathrm{AQ})=$ Adoption score obtained by respondent $X 100$ Maximum possible adoption score

Overall adoption level in the area was also worked out by calculating the arithmetic mean of the adoption quotient of all the respondents as below:

Overall adoption Level $=\mathrm{AQ} N \sum$

Where, $\mathrm{AQ}=$ Adoption quotient for the respondents

$\mathrm{N}=$ Total number of respondents

The adoption scores assigned to each respondent was totaled and mean scores of adoption ( $\mathrm{x}$ ) and standard deviation (SD) were computed. Adoption behavior was categorized into three levels i.e. (I) low extent of adoption, if the total score of an individual respondent is below Mean- SD (ii) medium extent of adoption, if the score varies from Mean- SD to Mean + SD and (iii) high extent of adoption, if individual score is above Mean+SD.

\section{Results and Discussion}

\section{Socio-economic profile of respondents}

Characteristics representing the personal and socio-economic attributes like family size and caste, social participation, educational status, experience in aquaculture and income are presented in Table 1. It is clearly evident from table that the majority of the beneficiary respondents belonged to middle age group $(47.22 \%)$ followed by young age group
(34.72\%) and old age group (18.\%). Similar trend was also observed in case of the nonbeneficiary respondents. More than half of the respondents preferred the nuclear family having medium family size i.e. 5-10 members. Majority of the respondents both beneficiary (45.84\%) and non-beneficiary (48.33) involved in agricultural production were literate having high level of education. But, social participation level of nearly 65 per cent of the respondents was medium. It was observed the majority of respondents were possessing medium sized land holding with medium level of socio- economic status. The frequency distribution of respondents on their farm family income appears to be better in case of beneficiary respondents of the KVKs, than those of non-beneficiary respondents. The frequency distribution of respondents appears to be highly skewed towards higher side of economic motivation among the respondents from adopted villages of KVK. In case of non adopted villages, the frequencies fell into a more or less normal distribution, though slightly skewed towards lower side of economic motivation. More than one third of respondents in adopted villages of $\mathrm{KVK}$ expressed higher levels of economic motivation. But in case of farmer respondent from non-adopted villages 36 percent had lower levels of economic motivation. The respondents had moderate level of extension contact having moderate exposure to mass media.

\section{Level of adoption}

The data presented in Table 2 revealed that nearly 85 per cent beneficiary respondents had high to medium level of adoption of improved agricultural production technologies. While, only 15.83 per cent of the respondents had low level of adoption. In case of non-beneficiary respondents majority of the farmers (45.00 per cent) had low level of adoption of improved technologies. The 
results clearly indicate that the nonbeneficiary respondents seem to have the least level of adoption as is evident from the lowest number of farmers having high adoption and high number in the category of low to medium adoption. Results so arrived because of the fact that the vocational training, front line demonstrations and on-farm testing, conducted by the scientists of Krishi Vigyan Kendra, were motivated the farmers to adopt improved technologies. Supporting these results (Sharma, 2002) concluded that the farmers of adopted villages adopting more practices of improved technologies as compared to the farmers of non-adopted villages. (Chauhan 2012) stated that the adoption level of the tribal farmers was amplified after imparting training and conducting frontline demonstrations by Krishi Vigyan Kendra. According to (Behera et al., 2014) KVK playing a vital role in disseminating the improved crop production technology and helps in increasing the crop yield. The technology transferred is also profitable and acceptable to the farming community. Similary (Kharatmol, 2006) was also reported that majority of the trained respondents $(45.00 \%)$ had high level of adoption followed by medium $(40.00 \%)$ and low level of adoption (15.00\%).

Table.1 Distribution of respondents according socio economic and personal characteristics

\begin{tabular}{|c|c|c|c|c|c|}
\hline \multirow{3}{*}{ Characteristic } & \multirow{3}{*}{ Attribute } & \multicolumn{4}{|c|}{ Respondents } \\
\hline & & \multicolumn{2}{|c|}{ Beneficiary $(n=120)$} & \multicolumn{2}{|c|}{ Non-Beneficiary $(n=60)$} \\
\hline & & Frequency & Percentage \%) & Frequency & Percentage \%) \\
\hline \multirow[b]{3}{*}{ Age } & Below 35 years & 57 & 47.50 & 27 & 45.00 \\
\hline & $35-50$ years & 45 & 37.50 & 23 & 38.33 \\
\hline & $\begin{array}{c}\text { More than } 50 \\
\text { year }\end{array}$ & 18 & 15.00 & 11 & 18.33 \\
\hline \multirow{3}{*}{ Family type } & Nuclear & 69 & 57.50 & 32 & 53.33 \\
\hline & Joint & 51 & 42.50 & 28 & 46.67 \\
\hline & $\begin{array}{l}\text { Small ( Up to } 5 \\
\text { members) }\end{array}$ & 66 & 55.00 & 40 & 66.67 \\
\hline Size of family & $\begin{array}{l}\text { Medium }(5-10 \\
\text { members })\end{array}$ & 54 & 45.00 & 20 & 33.33 \\
\hline \multirow[t]{3}{*}{ Education } & $\begin{array}{l}\text { Literate (can } \\
\text { read and write) }\end{array}$ & 55 & 45.84 & 29 & 48.33 \\
\hline & $\begin{array}{l}\text { Educated (up to } \\
10+2 \text { level) }\end{array}$ & 52 & 43.33 & 26 & 43.33 \\
\hline & $\begin{array}{c}\text { Highly educated } \\
\text { (graduate and } \\
\text { above) }\end{array}$ & 13 & 10.83 & 05 & 08.34 \\
\hline \multirow{3}{*}{$\begin{array}{l}\text { Social } \\
\text { participation }\end{array}$} & Low & 32 & 26.67 & 17 & 28.33 \\
\hline & Medium & 81 & 67.50 & 39 & 65.00 \\
\hline & High & 7 & 5.83 & 04 & 6.67 \\
\hline \multirow{2}{*}{$\begin{array}{l}\text { Socio-economic } \\
\text { status }\end{array}$} & Low & 15 & 12.50 & 21 & 30.00 \\
\hline & Medium & 63 & 52.50 & 27 & 45.00 \\
\hline
\end{tabular}




\begin{tabular}{|c|c|c|c|c|c|}
\hline & High & 42 & 35.00 & 12 & 25.00 \\
\hline \multirow{2}{*}{$\begin{array}{l}\text { Operational } \\
\text { land holdings }\end{array}$} & Marginal & 12 & 10.00 & 05 & 8.33 \\
\hline & Small & 108 & 90.00 & 55 & 91.67 \\
\hline \multirow[t]{3}{*}{$\begin{array}{l}\text { Annual family } \\
\text { income }\end{array}$} & $\begin{array}{l}\text { Up to Rs. } \\
60,000 /-\end{array}$ & 10 & 8.33 & 05 & 8.33 \\
\hline & $\begin{array}{l}\text { Rs. } 60000 \text { to } \\
\text { Rs. } 90,000 /-\end{array}$ & 20 & 16.67 & 10 & 16.67 \\
\hline & $\begin{array}{l}\text { Rs. } 90000 \text { to Rs. } \\
110,000 /-\end{array}$ & 90 & 75.00 & 45 & 75.00 \\
\hline \multirow{3}{*}{$\begin{array}{l}\text { Agricultural } \\
\text { progressiveness }\end{array}$} & Low & 29 & 24.17 & 23 & 38.33 \\
\hline & Medium & 53 & 44.17 & 29 & 48.33 \\
\hline & High & 38 & 31.67 & 08 & 13.33 \\
\hline \multirow{3}{*}{$\begin{array}{l}\text { Extension } \\
\text { contact }\end{array}$} & Low & 16 & 13.33 & 29 & 48.33 \\
\hline & Medium & 61 & 50.84 & 09 & 15.00 \\
\hline & High & 43 & 35.83 & 22 & 36.67 \\
\hline \multirow{3}{*}{$\begin{array}{l}\text { Mass media } \\
\text { exposure }\end{array}$} & Low & 21 & 17.50 & 23 & 38.33 \\
\hline & Medium & 53 & 44.17 & 29 & 48.33 \\
\hline & High & 46 & 38.33 & 11 & 18.33 \\
\hline
\end{tabular}

Table.2 Distribution of respondents based on level of adoption

\begin{tabular}{|c|c|c|c|c|}
\hline \multirow{3}{*}{ Category } & \multicolumn{4}{|c|}{ Respondents } \\
\cline { 2 - 5 } & Beneficiary $(\mathbf{n = 1 2 0})$ & Non-Beneficiary & $(\mathbf{n = 6 0})$ \\
\cline { 2 - 5 } & Frequency & Percentage (\%) & Frequency & Percentage (\%) \\
\hline Low & 19 & 15.83 & 27 & 45.00 \\
\hline Medium & 58 & 48.33 & 26 & 43.33 \\
\hline High & 43 & 35.83 & 07 & 11.67 \\
\hline
\end{tabular}

Table.3 Overall adoption of improved agricultural production practices

\begin{tabular}{|l|l|l|r|r|r|r|}
\hline \multirow{2}{*}{\multicolumn{1}{|c|}{ Aspects }} & \multicolumn{3}{|c|}{ Beneficiary } & \multicolumn{3}{c|}{ Non-Beneficiary } \\
\cline { 2 - 8 } & $\begin{array}{l}\text { Total } \\
\text { Score }\end{array}$ & $\begin{array}{l}\text { Mean } \\
\text { Score }\end{array}$ & $\begin{array}{l}\text { Adoption } \\
\text { Quotient }\end{array}$ & $\begin{array}{l}\text { Total } \\
\text { Score }\end{array}$ & $\begin{array}{l}\text { Mean } \\
\text { Score }\end{array}$ & $\begin{array}{l}\text { Adoption } \\
\text { Quotient }\end{array}$ \\
\hline Preparatory cultivation & 459.71 & 3.83 & 76.62 & 185.76 & 3.10 & 61.92 \\
\hline Seed and Spacing & 450.00 & 3.75 & 75.00 & 191.25 & 3.19 & 63.75 \\
\hline $\begin{array}{l}\text { Cropping pattern and } \\
\text { crop rotation }\end{array}$ & 584.50 & 4.87 & 97.42 & 248.41 & 4.14 & 82.80 \\
\hline Fertilizer management & 410.17 & 3.42 & 68.36 & 171.322 & 2.86 & 57.11 \\
\hline Irrigation management & 359.75 & 3.00 & 59.96 & 143.21 & 2.39 & 47.74 \\
\hline Weed management & 363.50 & 3.03 & 60.58 & 154.49 & 2.57 & 51.50 \\
\hline Plant protection & 352.33 & 2.94 & 58.72 & 149.74 & 2.50 & 49.91 \\
\hline $\begin{array}{l}\text { Harvest and post harvest } \\
\text { operations }\end{array}$ & 406.00 & 3.38 & 67.67 & 172.55 & 2.88 & 57.52 \\
\hline
\end{tabular}


Table.4 Comparison between adoption quotients of beneficiary and non-beneficiary respondents

\begin{tabular}{|c|c|c|}
\hline \multicolumn{2}{|c|}{ Mean adoption quotient } & Calculated ' $t$ ' value \\
\hline Beneficiary Respondents & Non-Beneficiary Respondents & \\
\hline $\mathbf{7 0 . 5 4}$ & $\mathbf{5 9 . 0 3}$ & $\mathbf{6 . 7 1 2} * *$ \\
\hline
\end{tabular}

** Significant at $1 \%$ probability level

Overall adoption quotient for different aspects of agricultural production practices were analyzed and results presented in Table 3. If we have a cursory of table, it clearly indicates adoption quotient for different aspects of agricultural practices is highly skewed towards beneficiary respondents.

Further, in order to find out whether higher adoption quotient of beneficiary respondent was significant not the adoption quotient of beneficiary respondents was compared with the adoption quotient of non-beneficiary respondents by applying independent ' $t$ ' test. The data regarding this aspect have been presented in Table 4.

It was obvious from the Table 4 that the computed value of ' $t$ ' i.e. 6.712 were statistically significant at $1 \%$ probability level. It means adoption quotient of beneficiary respondent was significant higher over the adoption quotient of non-beneficiary respondents. This shows positive and significant impact of services of Krishi Vigyan Kendra on adoption of improved agricultural production practices. The results so arrived could be due to the exposure of beneficiary farmers to improved cultivation technologies through demonstrations, on farm trials and trainings conducted by Krishi Vigyan Kendra. Similar findings were also reported by (Malabasari and Hiremath 2016), (Sharma et al., 2014), (Behera et al., 2014), (Meena and Gupta 2013), (Dudi and Meena 2012), (Sharma et al., 2011), (Sahu et al., 2010), (Singh 2010), (Nagar et al., 2008) and (Sharma 2002).
It may be conclusion that the Krishi Vigyan Kendra contributed positively in enhancing the adoption level of farmers in various aspects of agricultural production technologies. KVK practices created great awareness and motivated the other farmers to adopt appropriate production technologies. Indeed the efforts of the KVK seemed to have a positive effect in enhancing the farmers' technical knowledge on agricultural production technologies. Due to the interventions of KVK scientists in training, demonstrations activities, on farm trials and other extension activities helped in enhancing the enhancing the knowledge level of farmers which in turn led higher adoption of agricultural production technologies.

\section{References}

Behera, S.K.; Maharana, J.R. and Acharya, P. (2014). Transfer of Technology through Krishi Vigyan Kendra for the Tribal Farmers in Hilly Areas of Koraput District. Indian Journal of Hill Farming, 27(2):34-37.

Chauhan, N.M. (2012). Impact and yield gap analysis of trainings and FLDs regarding scientific practices of chick pea (Cicer arietinum). International J. Ext. Edu., 8: 44-47.

Dudi, A. and Meena, M.L. (2012). Adoption of improved mustard production technology in Pali district of Rajasthan. International J. Ext. Edu., 8: 5-8.

Kharatmol, S.N. (2006). Impact of trainings conducted on vermicompost by Krishi Vigyan Kendra, Bijapur. M. Sc.(Agri.) 
Thesis, Univ. Agric. Sci., Dharwad, Karnataka (India).

Malabasari, R.T. and Hiremath, U.S. (2016). Effect of krishi Vigyan Kendra training programmes on knowledge and adoption of home science and agricultural technologies. J. Farm Sci., 29(2): 251-256.

Meena, K.C. and Gupta I.N. (2013). Impact of KVK Training Programmes on Adoption of Garlic Production Technology. Journal of Krishi Vigyan, 1(2): 41-43.

Nagar, S.N.; Chauhan, M.S.; Sharma, F.L. and Sharma, V.P. (2008). Adoption of recommended coriander cultivation technology among the farmers of Atru tehsil in Baran district of Rajasthan. Rajasthan J. Ext. Edu., 16:190-194.

Sahu, P.R., Prasad, A. and Ram, D. (2010). Adoption of improved wheat cultivation technologies in Unnao district of Uttar Pradesh. Indian Res. J. Ext. Edu., 10(2): 25-28.

Sharma, A.K.; Kumar, V.; Jha, S.K. and Sachan, R.C. (2011). Frontline demonstration on Indian mustard: An impact assessment. Indian Res. J. Ext. Edu., 11(3): 25-30.

Sharma, M.; Singh, G. and Keshava. (2014). Impact evaluation of training program meson dairy farming in Punjab State. Indian Research Journal of Extension Education, 14(1):105-108.

Sharma, R.P. (2002). Impact of $\mathrm{kvk}$ on knowledge, altitude, adoption and diffusion of improved technology. Indian J Agric. Res., 36 (4): 248 - 253.

Singh, B. (2010). Adoption of Mungbean production technology in arid zone of Rajasthan. Indian Res. J. Ext. Edu., 10(2): 73-77.

\section{How to cite this article:}

Chaudhary, K. P., Santosh Kumar, N. Jotish, Joshi Kumar and Lalvensanga, P. 2021. Extent of Adoption of Improved Agricultural Production Practices in Aizawl District of Mizoram. Int.J.Curr.Microbiol.App.Sci. 10(01): 86-92. doi: https://doi.org/10.20546/ijcmas.2021.1001.010 